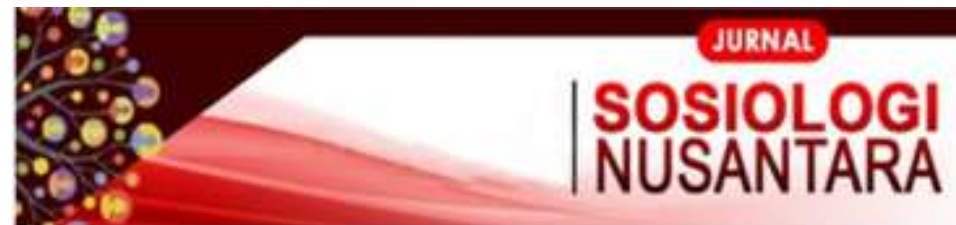

https://ejournal.unib.ac.id/index.php/jsn
ISSN Print : $2460-9099$

ISSN Online : 26229.9617

\title{
CONSEQUENCES OF NEPALESE YOUTH MIGRATION TO OVERSEAS FOR FOREIGN EMPLOYMENT
}

\author{
Pankaj Das', Praptini Yulianti² \\ pankajdas360@gmail.com
}

${ }^{12}$ Department of Management, Faculty of Economics and Business, Universitas Airlangga

\begin{abstract}
Nepal is an agricultural country, where migration is increasing for foreign employment. Majority of workers from Asia mostly from Nepal migrate to Middle East countries. Migrant workers working in these countries suffer from work related risk like accidents at workplace and mental sickness. Foreign migration has shifted the agricultural economy towards remittance based economy. Lack of education and limited employment opportunities are the main reasons behind international labor migration. The issue of such migration needs to be addressed at the government level, to assist in managing and promoting safe migration in an effective way.
\end{abstract}

Keywords : Foreign Employment, Health risks, Migration

\section{INTRODUCTION}

Nepal has a long history of labour migration. Nepalese people have been leaving their homes for employment and living abroad for around 200 years (Gurung, 2004). The history of labor migration begins in 1814-1816, after the Nepal-British India war (Kunwar, 2015). For the past several decades, India has been one of the key destinations for Nepalese workers and continues to be the largest destination country. Nepal and India shares an open border and Nepal-India friendship treaty (1955) gives the freedom to the citizens of each countries for free movement in both the countries. The movement is further enhanced due to similar culture and languages. Although Nepalese people working in India are large in number (approximately 3 million), sufficient data regarding their number and remittance generated by them is not available since visa and work permit are not required to work in India.

International labour migration has 30 year long history in Nepal (Bhattarai, 2005). This migration mostly occurs in Gulf Nations, Malaysia and other South East Asian countries. The government of Nepal approved the Labour Act of 1985 which officially recognized the potential value of foreign labour migration. Since then the trade unions in Nepal began to show an interest in overseas workers. From the late 1980s on wards, Nepalese 
workers started to move outside the Indian sub-continent for the jobs. In the successive years, Nepalese began to migrate to the gulf countries to work mainly Saudi Arabia, the United Arab Emirates (UAE), Kuwait, and Qatar. By 2002, approximately 170,000 Nepalese were working in East and Southeast Asia (UNIFEM), however at the same time over 465,000 Nepalese worked in Saudi Arabia and Bahrain.

Most of the migrants, about 90 percent of those who migrate for work, migrate to Saudi Arabia, Qatar, UAE and Malaysia. These countries are the high-cost-high-return destinations for Nepalese workers. This is contrary to India which is regarded as low-costlow-return destination. Migration to overseas countries is facilitated institutionally. The agreements made between Malaysia and the Gulf countries are relatively easy. However it is costly, still Nepalese workers migrate for (low-skilled) work in those destinations. In 2014, almost 500,000 workers left Nepal to work in these destination countries.

The migration of workers from South Asia to Middle East and other parts of the world is mainly attributed to the oil boom which started in the early 1970s (Bhattarai, 2005). Eventually this resulted in rapid industrialization, growth of automobile industries, and tourism and real-estate business in these countries. Since, these development activities demanded more and more workers, thus, there were job vacancies for foreign laborers.

From the start of $21^{\text {st }}$ century, overseas employment has rapidly increased, particularly after globalization. It has generated enormous remittance money; transforming the agricultural economy of Nepal into a remittance economy (Wagle, 2012). Currently, Nepalese economy is heavily dependent on remittance sent home by migrant workers. At a time when Nepalese economy faced several challenges of political instability and insecurity, remittances played a crucial role in poverty alleviation and improving the life standards of the people (Shrestha, 2008).

\section{RESEARCH METHODS}

This is a qualitative descriptive study on Nepalese youth migration to foreign countries. In this study, information was reviewed from the recently published articles on relevant issues. 


\section{DISCUSSIONS}

\section{Major causes of labour migration in Nepal}

Nepal is a land-locked country located in between two giant countries of Asia i.e. China and India. They are the fast developing countries in the world in terms of economy and technology while Nepal still faces major challenges due to poor infrastructures and geography. Nepal has a vast resources like water, land, landscapes, forest etc. But it lacks the leadership in order to manage these resources. The government often plays a pivotal role in development activities, mobilize the available resources and manpower. However, both seems a far dream for Nepal. Corruption and inefficiency of the political leaders are taken as root problems of the prevailing unemployment in the country.

Education and Health are considered an important indicator of development in a country. But the state of these infrastructures is in unmanaged stage. There is very little investment from the government sector; larger proportion of the investment is from the private sector. As a result, there is no equal and fair access for the ordinary or poor citizens. Nepalese society faces a burning challenge of transportation throughout the country. The existing road network cannot ensure safety connectivity. As more than 80 percent of the landmass is mountains or hills, there is no access in many parts of the country and thus remains the remote area. Furthermore, Nepal is an agriculture country; the country's economy heavily depends on agriculture but the agriculture depends on monsoon rain. This is an ugly truth and those who depend on agriculture job are often vulnerable to rain; moreover, their income may not be enough to feed themselves or their family or to fulfill their daily needs.

\section{Consequences of labour migration}

The migrant workers have to face many problems while taking the decisions to migrate for foreign employment. Similarly, they have to face the problems of finding sufficient money to go abroad and the only way to get money is through a loan with at high interest rate. Most of them are not aware about where they are going, what kind of work they have to do, the actual cost they need to spend to go for work, and other social and cultural information about the destination country. As a result of this, there are numerous of real stories of Nepalese migrants suffering a lot in abroad.

Many migrant workers are working in critical situations without any effective legal protection like health and safety. Workplace exploitation by foreign companies is well known but the Nepalese government has not adopted any specific labour diplomatic relations except in some cases. Though the workers are not allowed to work everywhere around the world, 
there are various serious cases about the pathetic situation of Nepalese workers working in unauthorized countries without any proper protection by the host countries. The massacre of 12 Nepalese workers on August 2004 by an extremist group in Iraq can be taken as a good example (Bhattarai, 2005). There are many other cases where illegal Nepalese workers are kept in prison for a long time on both fraud and genuine charges. Nevertheless, the Nepalese government has not adopted legal political diplomacy to rescue them and assure their safe return to the homeland. Thus, the issue of international labour migration needs to be addressed at the policy level, which could assist in managing and promoting safe migration in an effective way.

It has been estimated that in recent years more than 500 Nepalese people per day go abroad for foreign employment (Graner, et al., 2003; Thieme, et al., 2005; Gaudel, 2006; Seddon, et al., 1998). Lack of proper education, existing poverty, limited employment opportunities, deteriorating agricultural productivity and armed conflict are some of the reasons for overseas employment (Thieme, et al., 2005). Nepalese workers are migrating to different countries especially from middle or low class families for short period. Further, migration helps such citizens as a source of income for their families, thereby stimulating the country's economy (Central Bureau of Statistics, Government of Nepal, 2011; Dhungel, 2014). Foreign remittance sent by Nepalese workers to Nepal represents $26.4 \%$ of Nepal's gross domestic product (Nepal Rastra Bank, 2014).

In Gulf Countries, most of the Nepalese workers, even at high temperature, are involved in heavy manual labour such as road building sites, construction sites (Seddon, et al., 1998). However, the situation is worst for Nepalese workers in Gulf Countries (Malla, et al., 2017). Nepalese workers have high chance of accidents and suffering from other health problems because of the long working hours, and poor living and working conditions. Academic research (Joshi, et al., 2011) and the popular press (Gattoni, 2015) have detailed the terrible working conditions of Nepalese workers (young men age of 20 to 35 years) mostly in Gulf countries. The reality is that migration to the Gulf Country often leads to numerous deaths, sexual violence, and chronic illness among young Nepalese (Modarres, 2010; Stephenson, 2015).

\section{State of Nepalese workers in Qatar}

The large number of Nepalese workers died in Qatar while building the infrastructure to host 2022 World Cup. While building the World Cup infrastructure, 185 Nepalese construction workers died. If this incidents happen, an estimated 4,000 migrant workers will 
die before the launch of Qatar's World Cup in 2022 (Erfani, 2015). The embassy receives about number of complaints each day from Nepalese victims. Nepalese workers are forced to work 10 to 14-hours in a day in Qatar, often in extreme heat, with few hours of sleep, and live in cramped accommodation. Most of the people working here have gone into debt just to go to Qatar and frequently have to work overtime to meet their needs. Some make only onethird of the money that they are initially promised by the agents. Even they have not been paid in months and have no healthy food or proper shelter.

Their passports were confiscated by their employers (Gibson, et al., 2014) so they are not able to leave the country without the permission from the respective authorized officer. Further, some migrant workers reported poor, unsanitary living conditions and being trapped by their officer. Most of the workers sharing same toilet and live in a dark, small room. Even they are not getting the proper foods to eat. Every day, they only eat bread and drink water; without money, they cannot afford anything else. They are living in an exploitative environment and also the salary is very low for the survival.

When 8,000 Nepalese people died due to earthquake in 2015, Qatar refused to let their Nepalese workers to leave for attending the funerals of their family members in Nepal. As they have to complete the World Cup Construction sites on time. They also get fear that if Nepalese people return to Nepal, these people will not come back to work. Few workers from other sectors were allowed to return back, however those working on World Cup construction sites were not allowed to leave. The government of Nepal even offered to pay for the workers' flights home to attend funeral services but the Qatar companies would not allow them bereavement leave. The Nepalese workers have to pay charges such as processing fees, visa fees, and flight tickets to recruitment officers in Nepal. This means when Nepalese workers arrive in Qatar, they are in a massive amount of debt before working. Most of the international companies working in Qatar do not meet safety requirements standard and as a result many construction workers lose their lives through this gross negligence of proper safety at the site areas. Qatar has poorly treated the migrant workers. As a result, the high number of deaths caused during the construction of the World Cup stadium.

In September 2013 The Guardian published a report (Pattisson, 2013) stating that since the beginning of the construction works on the future World Cup sites, an average of one Nepalese worker had died every day and if the works continued in the same manner this would result in the death of more and more Nepalese workers before the beginning of the event. Amnesty International has called on FIFA to take responsibility and address the issue of migrant workers in Qatar (Thomson, 2014). This means that migrant workers not only 
know virtually nothing about the terms of their contracts and their future working conditions, but not being able to either quit their job nor leave the country. Based on all of these factors it is safe to say that the kafala system is not only meant to enhance Qatari lives but it also serves as a legal framework that enables slave-like working conditions. It is also not hard to argue that the kafala system can be considered a blatant violation of international labour law.

Qatar is a member of the International Labour Organization (ILO) which is a specialized agent of the UN, established in 1946, to act as a supervisory system monitoring the implementation of conventions ratified by governments regarding issues like minimum wage, limitation of working hours, collective bargaining rights, protection of migrant workers and the abolition of labour force. Qatar has ratified several ILO conventions since joining the organization in 1976 and even though there are 71 conventions not ratified by the country. The biggest cause for concern as Erfani (2015) argues that Qatar has not incorporated these principles into its legislative mandates. Implicitly there are some notable ILO conventions among the ones Qatar has not ratified, like the Right to Organize and Collective Bargaining and the Freedom of Association and Protection of the Right to Organize Convention (Crocombe, 2014) which means that the Qatari labour system fundamentally lacks all forms of unionism and basically no form of protection exists against anti-union discrimination of migrant workers. Qatar will only initiate changes in its labour system if its world leading economic position is threatened and this is where the global responsibility of all companies and individuals contracting to build Qatari investments comes in. Labour rights violations in Qatar are not locally isolated problems but are largely determined by global politics and economic interest.

Nepalese government is actively promoting international labour migration and to safeguard the interests and welfare of migrants; however, only a few initiatives have been taken so far that. After the bilateral talks with the governments of the Gulf States about increasing the number of posts for Nepalese, and hence to improve the migrants' employment condition. Therefore, a number of Gulf States and Asian countries to which Nepalese workers may be officially recruited are listed and conditions for registered recruiting agencies should be defined and must be recognized by the Nepal Government. The Nepal government, on the one hand, is incapable of implementing existing policies properly and on the other hand, there are several things yet to do in the regulation and management of foreign labour migration. Basic improvements have done which include amending existing laws, promoting labour markets through labour diplomacy, and administering manpower agencies and welfare 
activities. International provisions are found to be very sound and applicable in the protection of migrant workers' right. However, governments in both sending and receiving countries do not seem genuine in their domestication of the spirit of international instruments, conference recommendations and plans of action. Manpower agencies are almost unfair in their dealings with the workers and their professionalism is questionable. The role of trade union organizations is also found to be ineffective in addressing the issues of potential labour migrants in the home country as well as in the country of destination. Consequently, the current need is for more effective migration management to reduce the vulnerabilities of migrant workers and to safeguard the rights of migrant workers.

\section{CONCLUSIONS}

There are two-third of Nepalese workers working in Gulf Countries. It is important for such country to understand human rights and migrant worker issues. The Government of Nepal and host country make sure that the migrant workers grasp health insurance to improve worker's minimum life standard. The migrant workers must be aware of their health risks and rights in relation to health services in the destination countries. Further, there is a lack of adequate information for the migrants making them aware of their health risks and the government of Nepal have to be responsible for providing such information. It is essential to implement the certain criteria for making the employee working in the suitable environment. To allow migrant workers to leave their jobs at their will as in any other developed nation, To pay migrant workers a fair and livable wage, To provide safe working conditions on construction sites

\section{REFERENCES}

Amnesty International. 2013. The dark side of migration: Spotlight on Qatar's construction sector ahead of the World Cup.

Bhattarai, P. 2005. Migration of Nepalese youth for foreign employment: Problems and prospects. Report, Youth Action Nepal, Katmandu.

Crocombe, N. G. 2014. Building a new future: the 2022 FIFA World Cup as a potential catalyst for labor reform in Qatar. Suffolk Transnat'l L. Rev., 37, 33.

Dhungel, K. R. 2014. Does remittance in Nepal cause gross domestic product? An empirical evidence using vector error correction model. International Journal of Econometics and Financial Management. 2(5), 168-174.12.

Erfani, A. 2015. Kicking Away Responsibility: FIFA's Role in Response to Migrant Worker Abuses in Qatar's 2022 World Cup. Jeffrey S. Moorad Sports LJ, 22, 623. 
Gaudel, Y. S. 2006. Remittance Income In Nepal: Need For Economic Development. Journal of Nepalese Business Studies. 3(1), 9-17.

Gibson, O., \& Pattisson, P. 2014. Death toll among Qatar's 2022 World Cup workers revealed. The Guardian, 23 (December).

Graner, E., \& Gurung, G. 2003. Arab ko lahure: Looking at Nepali labour migrants to Arabian countries. Contributions to Nepalese Studies. 30(2), 295-325.

Gurung, G. 2004. An overview paper on overseas employment in Nepal, 2004. ILO, Nepal.

Human Rights Watch. 2012. Building a better World Cup: Protecting migrant workers in Qatar ahead of FIFA 2022.

International Business Times. 2015. Nepali Minister Blasts Qatar, FIFA, Over Treatment of World Cup Migrant Workers.

Joshi, S., Simkhada, P., \& Prescott, G. J. 2011. Health problems of Nepalese migrants working in three Gulf countries. BMC International Health and human rights, 11(1),3.

Kunwar, L. S. 2015. Emigration Of Nepalese People And Its Impact. Economic Journal of Development Issues. 77-82.

Malla, B., \& Rosenbaum, M. S. 2017. Understanding Nepalese labor migration to Gulf countries. Journal of Poverty. 21(5), 411-433.

Nepal Rastra Bank. 2014. Monetary policy for fiscal year 2014/15. Retrieved from http:// www.nrb.org.np/ofg/monetary_policy/Monetary_Policy_(in_English)-2014-15_(Full Text).pdf

Pattisson p. 2013. Nepalese workers in Qatar: exploitation of migrants starts at home. The Guardian.

Seddon, D., Gurung, G., \& Adhikari, J. 1998. Foreign labour migration and the remittance economy of Nepal. HIMALAYA. The Journal of the Association for Nepal and Himalayan Studies, 18(2), 7.

Shrestha, B. 2008. Contribution Of Foreign Employment And Remittance To Nepalese Economy. Nepal Rastra Bank Economic Review, 1-15.

Thieme, S., \& Wyss, S. 2005. Migration patterns and remittance transfer in Nepal: A case study of Sainik Basti in western Nepal. International Migration.43(5), 59-98.

Thomson Reuters. 2014. Amnesty Calls on FIFA to Address Qatar Worker's Rights.

Wagle, U. R. 2012. Socioeconomic implications of the increasing foreign remittance to nepal: evidence from the nepal living standard survey. International Migration. 50(4), 186-207. 